\title{
The Effect of T-STEM Designation on Charter Schools: A Longitudinal Examination of Students' Mathematics
}

\section{Achievement ${ }^{*}$}

\author{
Ayşe Tuğba ÖNER ${ }^{* *} \quad$ Robert M. CAPRARO ${ }^{* * *}$ \\ Mary Margaret CAPRARO ${ }^{* * *}$
}

\begin{abstract}
STEM interested students and graduates shape the future of a country. However, in the U.S., the number of STEM graduates was not sufficient; therefore, to increase this number, STEM school designation started. The number of STEM schools has been increasing and Texas was one of the states showing growth over time. STEM schools in Texas (T-STEM) were converted from different schools by specific procedures. The highest number of T-STEM conversion was from charter schools. The effectiveness of T-STEM charter schools compared to regular charter schools (non-T-STEM charter) was worth to examine because the number of T-STEM schools converted from charter schools was noteworthy. Moreover, the most important goal of T-STEM schools was to improve students' STEM achievement. In this study, to investigate the effectiveness of T-STEM charter schools, students' mathematics achievement over three years (through high school) was examined. There were 1481 participants in the study. To have comparable two groups, propensity score matching was used. After matching, hierarchical linear modeling was used to analyze students' mathematics achievement longitudinally considering student variables. The findings showed that T-STEM charter schools were effective to increase one minority group's (i.e. Hispanic students) mathematics achievement over time.
\end{abstract}

Keywords: STEM; Texas STEM schools; charter schools; mathematics achievement.

\section{T-FeTeMM Tayininin Sözleşmeli Okullar Üzerine Etkisi: Öğrencilerin Matematik Başarılarının Boylamsal İncelemesi}

Öz

FeTeMM'e ilgi duyan öğrenciler ve FeTeMM (Fen, Teknoloji, Mühendislik, Matematik) mezunları bir ülkenin geleceğini şekillendirir. Fakat Amerika Birleşik Devletleri'nde, FeTeMM mezunlarının

\footnotetext{
* This study was a part of first author's dissertation study.

** Ph.D., Turkey, atugbaoner@gmail.com

*** Professor, Texas A\&M University, Dept. of Teaching, Learning, and Culture, Aggie STEM, rcapraro@tamu.edu

${ }^{* * * *}$ Associate Professor, Texas A\&M University, Dept. of Teaching, Learning, and Culture, Aggie STEM, mmcapraro@tamu.edu
} 
sayısı yetersizdi ve bundan dolayı bu sayıyı artırmak için FeTeMM okul tayini başlamıştır. FeTeMM okullarının sayısı gün geçtikçe artmaktadır. Teksas'ta zamanla FeTeMM okulları sayısında artış görülen eyaletlerden birisidir. Teksas'ta yer alan FeTeMM okulları (T-FeTeMM) belirli prosedürler doğrultusunda farklı türlerde okulların FeTeMM okullarına dönüşümü ile oluşmuştur ve TFeTeMM okullarına en yüksek sayıda dönüşüm, sözleşmeli okullar tarafından yapılmıştır. TFeTeMM sözleşmeli okullarının etkililiğinin diğer sözleşmeli okullarla karşılaştırılarak incelenmesi önemlidir çünkü T-FeTeMM sözleşmeli okullarına dönüşen sözleşmeli okulların sayısı kayda değer bir sayıdır. Ayrıca T-FeTeMM okullarının en önemli amacı öğrencilerin FeTeMM başarısını artırmaktır. Bu çalışmada T-FeTeMM sözleşmeli okullarının etkililiğini araştırmak amacıyla öğrencilerin üç yıllık matematik başarısı incelenmiştir. Çalışmada 1481 katılımcı bulunmaktadır. Karşılaştırılabilir iki grubun oluşturulması için eğilim değerleri eşleştirme yöntemi kullanılmıştır. Eşleştirmeden sonra öğrenci değişkenleri de dikkate alınarak öğrencilerin boylamsal matematik başarılarını incelemek amacıyla hiyerarşik lineer modelleme yöntemi kullanılmıştır. Sonuçlar T-FeTeMM sözleşmeli okullarının, bir azınlık grubu olan Hispanik öğrencilerin matematik başarılarının artmasında zamanla etkili olduğunu göstermiştir.

Anahtar Kelimeler: FeTeMM, Teksas FeTeMM okulları, sözleşmeli okullar, matematik başarısı.

\section{INTRODUCTION}

To maintain successful leadership status, progress, and prosperity, the United States (U.S.) needs students interested in science, technology, engineering, and mathematics (STEM) and STEM graduates. In the future, these STEM graduates will become workers who drive the nation's innovation and generate new ideas (U.S. Department of Commerce Economics and Statistics Administration, 2011). To obtain more STEM workers, a greater number of STEM graduates are needed. To increase the number of STEM inclined individuals and STEM graduates, recommendations were proposed by the President's Council of Advisors on the Science and Technology (PCAST) and the National Research Council (NRC). These recommendations included but not limited to designing 1,000 new STEM schools (PCAST, 2010) with the aim of improving student achievement in STEM disciplines and enhancing the number of students interested in STEM.

Every year, the number of specialized STEM schools has been increasing in the U.S. and Texas was one of the states showing continuous growth. STEM schools in Texas (i.e., T-STEM) started to serve in 2006-07 at the first time and there were seven T-STEM schools in that year. The number of T-STEM academies increased to
65 in 2012-13. These schools were designated from different types of schools including charter schools. In 2012-13 academic year, almost $\% 70$ percent of stand-alone T-STEM schools were converted from charter schools. This showed that the number of T-STEM charter schools increased simultaneously with the number of T-STEM schools.

The percentage of converted charter schools to T-STEM schools was noteworthy compared to other school types. Due to high percentage, it is important to examine the effectiveness of $\mathrm{T}$ STEM charter schools compared to non-TSTEM charter schools. The implication of STEM curriculum might be one reason of the conversion, which is especially expected to increase students' STEM subject achievement. In this study, one of the STEM subject, mathematics, was chosen as student achievement and students' mathematics achievement in T-STEM charter schools and non-T-STEM charter schools were compared longitudinally.

\subsection{Charter Schools and T-STEM Academies}

In the U.S. education system, charter schools were one type of school in addition to traditional public schools. At the beginning of 1990s, charter schools were established for better education in the U.S. These schools were public schools under contract that were disentangled 
from many regulations. In 1995, the creation of charter schools was authorized in Texas with goals of (a) improving student achievement, (b) enhancing the opportunity for learning in a public education system, (c) supporting new learning methods, (d) constituting opportunities for gaining additional teachers to the current system, and (e) creating a new form of accountability (Taylor et al., 2011). Accountability was an important factor for charter schools because if schools did not meet sufficient criteria, they could be discharged from their role as a charter school (Nathan, 1996). Not meeting annual state academic and financial standards is one possible reason to close a charter school (Texas Education Agency, 2014).

STEM schools formed another group of schools in the U.S. The workforce need in the fields of science, technology, engineering, and mathematics has brought with it the need for STEM schools. To answer that need, many states have started to create STEM schools for students at different levels. Texas has created Texas-STEM (T-STEM) academies serving both middle and high school students beginning with the 200607 academic year. Since that time, the number of T-STEM academies has rapidly increased. The primary goals of T-STEM academies are to improve students' science and mathematics achievement in Texas (Avery, Chambliss, Pruiett, \& Stotts, 2010) and to increase the number of students who will pursue a degree and a career in STEM fields (Educate Texas, 2013).

A T-STEM academy could be a charter school, a district school, or a district charter school. These academies generally started off as a nonT-STEM academy because the designation required the completion of an application to the Texas Education Agency (TEA) to earn designation. Earning the T-STEM academy designation usually required meeting additional crite- ria as explained in the T-STEM Academy Design Blueprint (T-STEM ADB) (Avery, 2010).

To attain T-STEM academy designation, a school must apply for it. If they meet certain criteria, they become T-STEM academy eligible. One obvious criteria for becoming a T-STEM academy was to understand and follow the purpose of these academies. Criteria included: (a) improving students' mathematics and science achievement in Texas (Avery, 2010), (b) increasing the number of students who want to study and have a career in STEM fields, (c) empowering teachers through high quality professional development, and (d) promoting school leadership (Educate Texas, 2013). Other examples of criteria were: (1) targeting at-risk students, (2) requiring no enrollment restrictions, (3) implementing T-STEM Blueprint, and (4) making progress on the Blueprint continuum. To ensure that T-STEM academies follow these criteria, a T-STEM ADB was used.

T-STEM academies had their own design called the T-STEM ADB. This blueprint's role was to "guide school leaders on planning and implementation of T-STEM academies" (Young, House, Wang, Singleton, \& Klopfenstein, 2011, pp. 3). Within the T-STEM ADB, there were benchmarks and rubrics that assessed how TSTEM academies perform on those benchmarks. These benchmarks and rubrics played an important role in the T-STEM Academy model because they allowed reviewers to assess a T-STEM Academy's performance against their benchmarks.

The T-STEM ADB had seven benchmarks that have changed over time. The first blueprint was written in 2005 and revised in 2008. The currently available version of the blueprint was written in 2010 (Avery et al., 2010). Blueprint benchmarks include: (a) mission-driven leadership, (b) T-STEM culture, (c) student outreach, recruitment and retention, (d) teacher selection, 
development and retention, (e) curriculum, instruction and assessment, (f) strategic alliances, and (g) academy advancement and sustainability (Avery et al., 2010; Öner \& Capraro, 2016). The T-STEM $A D B$ is currently assessed with a T-STEM ADB Rubric. Academies are expected to make progress on each benchmark every year and serve as a role model school for STEM teaching and learning according to the $T$ STEM $A D B$ assessed with a specific rubric (Avery et al., 2010; Educate Texas, 2013). These benchmarks were aligned with the characteristics for a "well-structured STEM school culture" (see Öner, in press). The important components of a "well-structured STEM school culture" are: (a) STEM mission, (b) administration, (c) informal learning environment, (d) formal learning environment, (e) teachers, (d) STEM specialists, (e) community partners, (f) STEM-curriculum, (g) research-based instruction, (h) advance coursework, (i) assessments, and (j) outcome (Erdogan \& Stuessy, 2015; Marshall, 2010; Means, Confrey, House, \& Bhanot, 2008; Means, House, Young, Wang, \& Lynch, 2013; Öner, in press; Peters-Burton, Lynch, Behrend, \& Means, 2014; Subotnik, Tai, Rickoff, \& Almarode, 2010).

The main difference between T-STEM charter schools and non-T-STEM charter schools is the $T$-STEM ADB that aimed to promote a more effective STEM teaching and learning environment than other schools. Therefore, one could believe the reason behind the conversion was to increase students' STEM subject achievement. It is important understand if the conversion to a T-STEM academy was effective on students' academic achievement (i.e., mathematics).

\subsection{Charter Schools and STEM schools Ver- sus Traditional Public Schools}

Researchers examined the effectiveness of STEM schools and charters schools compared to traditional public schools, separately. The findings for both school types were mixed. In terms of charter schools, students in charter schools had higher scores than students in traditional public schools in mathematics (Barr, Sadovnik, \& Visconti, 2006; Choi, 2012; Pardo, 2013; Rose, 2013; Sahin, Willson, \& Capraro, 2013; Tuttle, Gill, Gleason, Knechtel, NicholsBarrer, \& Resch, 2013; Tuttle, Teh, NicholsBarrer, Gill, \& Gleason, 2010; Woodworth, Davis, Guha, Wang, \& Lopez-Torkos, 2008), science (Tuttle et al., 2013), reading (Barr et al., 2006; Gutierrez, 2012; Pardo, 2013; Rose 2013; Tuttle et al., 2010; Tuttle et al., 2013), English language arts (Woodworth et al., 2008), and social studies (Tuttle et al., 2013). On the contrary, another findings showed that traditional public schools students performed higher than their counterparts in reading (Gutierrez, 2012; Sahin et al., 2013; Shrout, 2009), mathematics (Gutierrez, 2012; Hinojosa, 2009; Sahin et al., 2013; Shrout, 2009; Turner, 2013), and science (Hinojosa, 2009; Turner, 2013).

As for STEM schools, when overall students' achievement in STEM schools and non-STEM schools were compared, some studies (Means, Wang, Young, House, \& Lynch, 2014; Scott, 2012; Young et al., 2011) showed difference between these schools whereas some studies (Bicer et al., 2015; Erdogan, 2014; Öner \& Capraro, 2016; Philips, 2013; Wiswall, Stiefel, Schwartz, \& Boccardo, 2014) showed no difference. Young and her colleagues (2011) and Scott (2012) reported that all students in STEM schools outperformed counterparts in $9^{\text {th }}, 10^{\text {th }}$ and $11^{\text {th }}$ grade mathematics as well as $11^{\text {th }}$ grade reading. When overall students were considered some researchers reported no difference between two schools type; however, when demographic variables was considered separately, then results showed difference. For instance, when gender was taken into account, female STEM students had higher scores than 
others in mathematics (Bicer et al., 2015; Erdogan, 2014), reading (Erdogan, 2014), and biology (Wiswall et al., 2014) whereas male students in STEM schools outperformed male non-STEM students in science (Erdogan, 2014; Wiswall et al., 2014), mathematics and reading (Erdogan, 2014). Hispanic students in STEM schools performed better than Hispanic students in non-STEM schools in mathematics, science and reading (Erdogan, 2014; Wiswall et al., 2014).

No prior research studies examined the effectiveness of STEM-charter schools and presented the comparison between two types of charter schools, STEM-charter and non-STEMcharter. This study shed light to the literature in terms of charter schools and STEM schools aspects. The investment that had been contributed so far to STEM schools was remarkable; therefore, it is vital to understand the effectiveness of STEM schools as well. Thus, in this study, the purpose was to examine students' mathematics achievement over time in T-STEM charter and non-T-STEM charter schools to determine difference between two schools and STEM schools' effectiveness on students' achievement.

\section{METHODOLOGY}

To examine students' achievement in mathematics over time, a quasi-experimental design, which included control (i.e., non-T-STEM charter schools) and treatment (i.e., T-STEM charter schools) groups, was used. In this study, two types of datasets, student and school, were used. TEA was the institute that the datasets were obtained. Propensity score matching was used to determine participants from non-TSTEM charter schools. For propensity score matching, schools level variables were used. Students' mathematics achievement over three years were analyzed by using hierarchical linear modeling, where student level variables were used.

\subsection{Participants}

There were 1481 participants in T-STEM academies and non-T-STEM charter schools in 201011, 2011-12, and 2012-13 academic years. Based in the demographics of schools, there were 825 (55.7\%) female, 1125 (76\%) Hispanic, 123 (8.3\%) Asian, 190 (12.8\%) White, 43 (2.9\%) African American, and 1015 (\%68.5) economically disadvantaged students in both groups of schools.

There were two types of T-STEM academies in Texas. One type was school-within-a school model where there are students who receive the benefits of the T-STEM model and students who do not. Another type was stand-alone model, where all students receive the benefits of the T-STEM model. In this study, only standalone T-STEM charter schools were used as treatment group. It was impossible to disaggregate data for school-within-a school model T-STEM academies. Therefore, 19 standalone T-STEM charter schools out of 21 standalone T-STEM academies were the interest of this study. However, the student data obtained from TEA was available for only 15 stand-alone T-STEM charter schools; therefore, 15 T-STEM charter schools were formed the treatment group of this study.

Propensity score matching was used to determine control group that was comparable to treatment group. School level variables were used for propensity score matching. 15 T-STEM charter schools were matched to 30 non-TSTEM charter schools. However after matching, only 29 of them were available in the student data for further analysis.

Because of the nature of a longitudinal dataset, at least two time-points were required. There- 
fore, students who did not have scores for at least two years were excluded. There were 14 T-STEM academies and 18 non-T-STEM charter schools in the student dataset after the elimination of students.

For student level analysis several variables were used. Students' gender, socioeconomic status (SES) (i.e., whether classified as economically disadvantaged), at-risk status, and ethnicity were independent variables. In addition to that, a dichotomous variable (i.e., 1 indicated TSTEM and 0 indicated non-T-STEM charter) was used to identify whether a school was either a TSTEM charter school or non-T-STEM charter school. Two additional variables were developed. Time and time-square variables were added and used to determine whether there was a linear or a quadratic growth over time. For the variable time, 0 indicated intercept (i.e., 2011), 1 indicated year 2 (i.e., 2012), and 2 indicated year 3 (i.e., 2013). The variable time-square was computed by squaring the time variable. Students' mathematics Texas Assessment Knowledge and Skills (TAKS) scale score was used as continuous dependent variable.

\subsection{Instrument}

To examine students' mathematics achievement, students' high-stakes test scores were used. TAKS was administered as the highstakes test in Texas until (TEA \& Pearson, 2013). In 2012, the State of Texas Assessments of Academic Readiness (STARR) was started to administer to $9^{\text {th }}$ graders. Same year, $10^{\text {th }}$ and $11^{\text {th }}$ graders took TAKS. In 2013, $9^{\text {th }}$ and $10^{\text {th }}$ graders took STARR test whereas $11^{\text {th }}$ graders took TAKS. The STARR was an end of course exam; therefore, it was administered for each course. However, the TAKS test was administered every year; thus it was applicable for longitudinal examination whereas the STARR was not. The latest longitudinal examination of students in Texas would be from 2011 to 2013 for ninth trough eleventh grade students. Therefore, in this study, students' ninth grade TAKS scores in 2010-11, tenth grade TAKS scores in 2011-12, and eleventh grade TAKS scores in 2012-13 were used.

One of the important coefficients that need to be reported is the reliability of the instrument. In this study, the reliability estimates obtained from TEA were reported. The reliability coefficients for the TAKS test for mathematics were 0.92 in 2011 and 2012, and 0.90 in 2013 (TEA \& Pearson, 2011, 2013, 2014).

\subsection{Propensity Score Matching}

Randomized experiments yield best and unbiased results indicating causal inference, however, it is often not easy to design (Shadish \& Steiner, 2010). Sometimes, researchers might not be able to design randomized experiments or the study might start to be examined after the intervention was given. Therefore, in this kind of situation there is a need to assign a control and an intervention group. Propensity score analysis is one method to aid researchers in assigning groups (Shadish \& Steiner, 2010; Thoemmes \& Kim, 2011). Propensity score matching is the probability of the participant to be assigned to the treatment condition according to the set of observed covariates that are measured before the intervention (Rosenbaum \& Rubin, 1983). With a propensity score analysis, it is possible to get unbiased causal effect estimates by including all relevant covariates (Thoemmes \& Kim. 2011). Because this study investigated the effectiveness of STEM teaching in T-STEM charter schools on students' mathematics achievement after T-STEM charter schools were designated, and because in this situation randomization is not possible, propensity score analysis was used as a matching strategy to obtain similar or closest matched groups. 
After the estimation of propensity scores, the matching method was another step. In this study, one-to-many matching was used. Oneto-many matching was one of the commonly used matching methods after one-to-one matching (Thoemmes \& Kim, 2011) (e.g., Capraro, Capraro, Morgan, Scheurich et al., 2015). The advantage of one-to-many matching was to increase statistical power compared to one-to-one matching (Shadish \& Steiner, 2010). In this study one-to-two matching was used because of the availability of the adequate matches (Thoemmes \& Kim, 2011), which was another important issue that one needs to consider.

The propensity score matching was conducted using $\mathrm{R}$ version 2.14.0. 15 T-STEM academies (i.e., the treatment group) were matched to 30 non-T-STEM charter schools. In the matching, the percentage of mobility, English proficiency (LEP), SES, at-risk, African American, Hispanic and White students were used from the school dataset.

\subsection{Data Analysis}

In educational studies, the transformation of individuals' knowledge and skills over time has been an important topic (Bryk \& Raudenbush, 1988). The aim of this study was to understand students' mathematics achievement growth through high school in two different groups of schools (i.e., T-STEM charter and non-T-STEM charter schools). Students' learning took place in schools and schools' characteristics can have substantial influence on their learning process (Bryk \& Raudenbush, 1988). In this study, the data had nested structures: (1) students' scores over three years and (2) students within schools. Therefore, hierarchical linear modeling (HLM) was used as a multilevel analysis.
In educational studies, dealing with hierarchical data structures is common because students exist within hierarchical social structures such as classroom, school, or school district (Osborne, 2000). These types of nested data structures have some problems. Independence of observations is one of the problems. Individuals in the nested data, due to its nature, are not fully independent from each other because these individuals tend to show similarities different from people randomly sampled from the population (Hox, 2002; Osborne, 2000). However, hierarchical linear modeling (HLM) avoids these problems and is a useful analysis technique for nested data structures (Hox, 2002; Raudenbush \& Bryk, 2002). Furthermore, if data is longitudinal and unbalanced, HLM would be an useful technique to analyze data (Snijders \& Bosker, 1999). Thus, a three level HLM was used to analyze students' academic achievement over three years. Level-1 included students' repeated measures. Level 2 had student variables nested within schools. Level 3 had school types (T-STEM charter or non-TSTEM charter school).

The first model, fully unconditional, was analyzed to determine whether the data was appropriate for higher levels (Raudenbush \& Bryk, 2002). The mathematics scores were labeled as MATH. The first model equations by levels were:

$$
\begin{aligned}
& \text { Level } 1 \text { Equation: } M A T H_{i j k}=\pi_{0 j k}+e_{i j k} \\
& \text { Level } 2 \text { Equation: } \pi 0_{j k}=\beta_{00 k}+r_{0 j k} \\
& \text { Level } 3 \text { Equation: } \beta_{00 k}=\gamma_{000}+u_{00 k}
\end{aligned}
$$

The formula $\rho=\tau_{\beta} / \tau_{\pi}+\tau_{\beta}$ was used to represent proportion of variance between schools, where $\tau_{\pi}$ is level-2 variance, and $\tau_{\beta}$ is level- 3 variance (Raudenbush \& Bryk, 2002).

After addition of time variables (i.e., TIME and TIMESQ) and TSTEM variable, respectively, the final model was developed. In the final 
model, student level covariates were added. The student level variables were gender, SES, at-risk status, and ethnicity. In terms of ethinicity, $76 \%$ of students were Hispanic. In addition, the $96 \%$ of Hispanic students were economically disadvanaged. The correlation coeffieicient of being economically disadvantaged and hispanic was 0.7. Thefore, in the analysis, instead of SES variable, only ethnicity variable was added to the model to represent both covariates' charasterictis.

The variable etnicity was recoded and White students were selected as the reference group. African American (i.e., ETH_B), Asian (i.e., ETH_A), and Hispanic (i.e., ETH_H) students were dummy coded in the dataset. In the final model TSTEM and student level covariates interaction effects were taken into account to examine the specific group of students' performance in T-STEM charter schools.

2.4.1. Process for accounting for time. For quadratic growth, the growth rate at each year can be computed by using the derivate of the level 1 equation. For instance, $M A T H_{i j k}=\pi 0 j k+$ $\pi 1 j k^{*}\left(T I M E_{i j k}\right)+\pi_{2 j k^{*}}\left(T I M E S Q_{i j k}\right)+e_{i j k}$, the average growth rate at the end of the second year (i.e., 2012) for mathematics would be $t=\pi_{1 j k}+$ $2^{*} \pi 2 j k^{*}(2012-2011)$ (cf., Raudenbush \& Bryk, 2002).

\section{RESULTS}

\subsection{Descriptive Summaries}

Descriptives statistics for all students' scores in mathematics for the baseline year, 2011, were represented in Table 1. Mean and standard deviation were reported by gender, ethnicity, and at-risk status (see Table 1). According to the mean scores, male students and not at-risk students had higher scores than female and atrisk students, respectively. Asian students scored higher than other students. In mathematics, the score ranking from highest to the lowest in terms of ethnicity was Asian, White, Hispanic, and Black, respectively. In addition, descriptive statistics for three years indicated positive parabolic trajectory for all students' mathematics scores (see Table 2).

Table 1. Students' Scores in Mathematics in the Baseline Year

\begin{tabular}{llcc}
\hline \multirow{2}{*}{ Variable } & Category & \multicolumn{2}{c}{ Mathematics } \\
\cline { 3 - 4 } Gender & Female & 2353.73 & \multicolumn{1}{c}{$S D$} \\
\cline { 2 - 3 } At-risk status & Male & 2371.30 & 242.81 \\
& At-risk & 2284.59 & 254.56 \\
\multirow{2}{*}{ Ethnicity } & Not at-risk & 2384.48 & 225.52 \\
& Asian & 2478.69 & 240.47 \\
& AA & 2285.14 & 182.81 \\
\hline
\end{tabular}

*AA: African American

Table 2. Students' Mean Score and Standard Deviations in Mathematics for Three Years

\begin{tabular}{lcc}
\hline Year & $\bar{X}$ & Mathematics \\
& \multicolumn{1}{c}{$S D$} \\
\hline 2011 & 2361.48 & 236.20 \\
2012 & 2293.11 & 167.57 \\
2013 & 2365.31 & 172.02 \\
\hline
\end{tabular}




\subsection{HLM Analyses}

The longitudinal data was analyzed using HLM 7 software. Three-level HLM was used to investigate students' mathematics achievement in T-STEM charter and non-T-STEM charter schools over time. The unconditinal model explored how much of the variation in outcome variable was within and between schools.
3.2.1. Unconditional model. The grand mean $\left(\gamma_{000}\right)$, the estimated within-school variance $\left(\tau_{\pi}\right)$, and between-school variance $\left(\tau_{\beta}\right)$ were shown in Table 3. According to the unconditional model, $83 \%$ of the variation in the mathematics achievement was within schools whereas $17 \%$ was between schools.

Table 3. Grand Mean, Within and Between School Variance for Mathematics

\begin{tabular}{lccc}
\hline Subject & Grand mean & Within-school variance $\left(\tau_{\pi}\right)$ & Between-school variance $\left(\tau_{\beta}\right)$ \\
\hline Mathematics & 2326.18 & 19900.58 & 4043.52 \\
\hline
\end{tabular}

3.2.2. The final model. The fourth model included student level and school level variables. The results of HLM analysis were represented in Table 7. The main effects of time $(p<0.001)$, timesq $(p<0.001)$, at-risk $(p<0.001)$, and gender $(p=0.01)$ were statistically significant in the first year for mathematics. The interaction effects for students' mathematics scores were statistically significant: (1) TSTEM $\times$ Hispanic $(p<0.03)$, (2) TSTEM $\times$ at-risk $(p=0.03),(3)$ time $\times$ TSTEM $(p$ $=0.009),(4)$ time $\times$ TSTEM $\times$ Asian $(p=0.007),(5)$ time $\times$ TSTEM $\times$ Hispanic $(p<0.001),(6)$ time $\times$ TSTEM $\times$ at-risk $(p=0.02),(7)$ timesq $\times$ TSTEM $(p=0.01),(8)$ timesq $\times$ TSTEM $\times$ Asian $(p=0.02)$,
(9) timesq $\times$ TSTEM $\times$ African American $(p$ $=0.03)$, and (10) timesq $\times$ TSTEM $\times$ Hispanic $(p$ $=0.003)$.

The $\gamma_{000}$ coefficient represtented the predicted initial year of White, not at-risk female student in a non-T-STEM charter school (i.e., reference student). For reference student, the predicted mathematics achievement was 2407.65. On average, such students in T-STEM charter schools scored 84.16 points lower than students in non-T-STEM charter schools in mathematics. The change of initial average mathematics scores of other students with regard to the reference group were presented in Table 4.

Table 4. The Change of Students' Predicted Mathematics Achievement by Demographics and School Type

\begin{tabular}{lcl}
\hline Demographic information & $\begin{array}{c}\text { Initial mathematics score } \\
\text { [Increased }(+) / \text { decreased (-) }]\end{array}$ & School Type \\
\hline Asian, not at-risk female & +58.45 & non-T-STEM charter \\
Asian, not at-risk female & +75.28 & T-STEM charter \\
African American not at-risk female & -79.32 & non-T-STEM charter \\
African American, not at-risk female & -84.26 & T-STEM charter \\
Hispanic, not at-risk female & -62.29 & non-T-STEM charter \\
Hispanic, not at-risk female & -27.36 & T-STEM charter \\
White, not at-risk male & +39.83 & non-T-STEM charter \\
White, not at-risk male & -87.23 & T-STEM charter \\
White, at-risk female & -110.0 & non-T-STEM charter \\
White, at-risk female & -162.6 & T-STEM charter \\
\hline
\end{tabular}


The predicted learning rate for the reference student group was -194.44 for mathematics. On average, a reference group student's mathematics score decreased 194.44 points per academic year. However, on average, a T-STEM charter student's learning rate decreased 60.97 points.
This showed that T-STEM charter schools average academic learning rate was 133.47 points higher than non-T-STEM charter schools per year. On average, students mathematics learning rate was shown in Table 5 by students' demographics and school type.

Table 5. The Change of Students' Predicted Mathematics Learning Rate by Demographics and School Type

\begin{tabular}{lcl}
\hline Demographic information & $\begin{array}{c}\text { Learning rate } \\
\text { [Increased }(+) / \text { decreased }(-)]\end{array}$ & School Type \\
\hline Asian, not at-risk female & +58.53 & non-T-STEM charter \\
Asian, not at-risk female & +6.11 & T-STEM charter \\
African American, not at-risk female & -19.30 & non-T-STEM charter \\
African American, not at-risk female & +162.66 & T-STEM charter \\
Hispanic, not at-risk female & +87.10 & non-T-STEM charter \\
Hispanic, not at-risk female & +29.26 & T-STEM charter \\
White, at-risk female & +1.03 & non-T-STEM charter \\
White, at-risk female & +218.88 & T-STEM charter \\
White, not at-risk male & +0.52 & non-T-STEM charter \\
White, not at-risk male & +165.42 & T-STEM charter \\
\hline
\end{tabular}

The mean accelaration was statistically significant $(p<0.001)$ and positive $\left(\gamma_{200}=86.96\right)$ in mathematics. From the descriptive analysis, it was seen that schools growth was not linear for mathematics performance. Therefore, there was a need for a variable (i.e., timesq) to estimate the accelaration rate of schools to examine their growth rate over time. At the end of the second year, the average growth rate for White, not atrisk female student in a non-T-STEM charter school was -20.52 $(-194.44+2(86.96) 1)$ points per year. For such students, by the end of the third year, the average growth rate had grown to 153.4 points per year. For a White, not at-risk female student in a T-STEM charter school, the average growth rate was 10.07 at the end of the second year. By the end of the third year, the average growth rate had grown to 81.11 points per year for a White, not at-risk female student in a T-STEM charter school. The mean accelaration rate for other students was shown in Table 6 by each year and school type.

Table 6. The Mean Accelaration Rate by Demographics, Year, and School Type in Mathematics

\begin{tabular}{|c|c|c|c|}
\hline \multirow[t]{2}{*}{ Demographic information } & \multicolumn{2}{|c|}{ Accelaration rate } & \multirow[t]{2}{*}{ School Type } \\
\hline & Second year & Third year & \\
\hline Asian, not at-risk female & 10.99 & -36.55 & non-T-STEM charter \\
\hline Asian, not at-risk female & -34.94 & 47.48 & T-STEM charter \\
\hline African American, not at-risk female & 39.56 & 98.4 & non-T-STEM charter \\
\hline African American, not at-risk female & -129.53 & -288.25 & T-STEM charter \\
\hline Hispanic, not at-risk female & 26.92 & -33.26 & non-T-STEM charter \\
\hline Hispanic, not at-risk female & -34.77 & 34.66 & T-STEM charter \\
\hline White, at-risk female & 0.95 & 0.87 & non-T-STEM charter \\
\hline White, at-risk female & 103.27 & 121.13 & T-STEM charter \\
\hline White, not at-risk male & 1.46 & 2.40 & non-T-STEM charter \\
\hline White, not at-risk male & 25.19 & 18.43 & T-STEM charter \\
\hline
\end{tabular}




\subsubsection{Auxiliary Statistics.}

There was statistically significant variation among students within schools for the initial year on mathematics. In addition, there was statistically significant variation on learning rate in mathematics. For mathematics, school grouping (TSTEM) explained an unimportant amount of the variation in the initial year $(0.6$ $\%)$ and in the learning rate $(0.1 \%)$. Each student level variable was added one at a time to estimate the variance accounted for by each varia- ble until all variables had been added. All three ethnicity variables, one of the student level variables, accounted for $2 \%$ of the parameter variance in the initial year. Ethnicity variables accounted for $0.5 \%$ of the parameter variance in growth rates for mathematics. The variable gender explained $0.4 \%$ variability in the initial year. At-risk variable accounted for $7 \%$ of the variation in the initial year, whereas $4 \%$ of the variation in growth rates for mathematics.

Table 7. Effects of Student and School Level Variables on Students' Mathematics Achievement

\begin{tabular}{|c|c|c|c|c|c|c|c|}
\hline \multirow[b]{2}{*}{ Fixed Effect } & \multicolumn{3}{|c|}{ Mathematics } & \multirow[b]{2}{*}{ Fixed Effect } & \multicolumn{3}{|c|}{ Mathematics } \\
\hline & Coefficient & $S E$ & $\begin{array}{l}t- \\
\text { ratio }\end{array}$ & & Coefficient & $S E$ & $\begin{array}{l}t- \\
\text { ratio }\end{array}$ \\
\hline Intercept & $2407.65^{*}$ & 38.84 & 61.98 & Time $\times$ Hispanic & $87.10^{*}$ & 32.10 & 2.71 \\
\hline TSTEM & -84.16 & 56.15 & -1.49 & $\begin{array}{c}\text { Time } \times \text { TSTEM } \times \text { His- } \\
\text { panic }\end{array}$ & $-191.31^{*}$ & 49.17 & -3.89 \\
\hline Asian & 58.45 & 42.34 & 1.38 & Time $\times$ at-risk & 1.03 & 27.02 & 0.03 \\
\hline TSTEM $\times$ Asian & 100.99 & 59.36 & 1.70 & $\begin{array}{c}\text { Time } \times \text { TSTEM } \times \text { at- } \\
\text { risk }\end{array}$ & $84.38^{*}$ & 38.66 & 2.18 \\
\hline $\mathrm{AA}^{* *}$ & -79.32 & 55.98 & -1.41 & Time $\times$ gender & 0.52 & 20.55 & 0.02 \\
\hline TSTEM $\times \mathrm{AA}^{* *}$ & 79.22 & 79.35 & 0.99 & $\begin{array}{c}\text { Time } \times \text { TSTEM } \times \text { gen }- \\
\text { der }\end{array}$ & 31.43 & 30.59 & 1.02 \\
\hline Hispanic & -62.29 & 39.15 & -1.59 & Timesq & $86.96^{*}$ & 12.57 & 6.91 \\
\hline TSTEM $\times$ Hispanic & $119.09^{*}$ & 54.82 & 2.17 & Timesq $\times$ TSTEM & $-51.44^{*}$ & 20.91 & -2.45 \\
\hline At-risk & $-110.00^{*}$ & 26.85 & -4.09 & Timesq $\times$ Asian & -23.77 & 20.15 & -1.17 \\
\hline TSTEM $\times$ at-risk & $-78.44^{*}$ & 36.25 & -2.16 & $\begin{array}{c}\text { Timesq } \times \text { TSTEM } \times \\
\text { Asian }\end{array}$ & $67.48^{*}$ & 30.85 & 2.18 \\
\hline Gender & $39.83^{*}$ & 15.65 & 2.54 & Timesq $\times \mathrm{AA}^{* *}$ & 29.43 & 35.88 & 0.82 \\
\hline TSTEM $\times$ gender & -42.90 & 23.15 & -1.85 & $\begin{array}{c}\text { Timesq } \times \text { TSTEM } \times \\
\mathrm{AA}^{* *}\end{array}$ & $-108.79^{*}$ & 52.21 & -2.08 \\
\hline Time & $-194.44^{*}$ & 30.26 & -6.42 & Timesq $\times$ Hispanic & $-30.09^{*}$ & 13.51 & -2.22 \\
\hline Time $\times$ TSTEM & $133.47^{*}$ & 47.47 & 2.81 & $\begin{array}{c}\text { Timesq } \times \text { TSTEM } \times \\
\text { Hispanic }\end{array}$ & $64.81^{*}$ & 21.84 & 2.96 \\
\hline Time $\times$ Asian & 58.53 & 45.99 & 1.27 & Timesq $\times$ at-risk & -0.04 & 11.95 & -0.01 \\
\hline $\begin{array}{c}\text { Time } \times \text { TSTEM } \times \\
\text { Asian }\end{array}$ & $-185.89^{*}$ & 68.22 & -2.72 & $\begin{array}{c}\text { Timesq } \times \underset{\text { TSTEM }}{\text { risk }} \times \text { at- } \\
\text { The }\end{array}$ & -8.89 & 17.44 & -0.51 \\
\hline Time $\times \mathrm{AA}^{* *}$ & -19.30 & 71.19 & -0.27 & Timesq $\times$ gender & 0.47 & 9.42 & 0.05 \\
\hline $\begin{array}{c}\text { Time } \times \text { TSTEM } \times \\
\mathrm{AA}^{* *}\end{array}$ & 48.49 & 99.21 & 0.48 & $\begin{array}{c}\text { Timesq } \times \text { TSTEM } \times \\
\text { gender }\end{array}$ & -3.85 & 14.05 & -0.27 \\
\hline
\end{tabular}

${ }^{*} p<0.05-{ }^{* *}$ AA: African American 


\section{CONCLUSION}

In this study, students' mathematics achievement in two types of schools, T-STEM charter schools and non-T-STEM charter schools, over three years was examined. In the state of Texas, the percentage of stand-alone T-STEM charter schools was noteworthy to investigate compared to stand-alone non-charter T-STEM academies. In addition, one could expect that students in T-STEM charter schools should perform better than counterparts in mathematics because of T-STEM academies' specific STEM model.

The results for mathematics performance of $\mathrm{T}$ STEM charter and non-T-STEM charter schools were mixed. T-STEM charter schools and nonT-STEM charter schools statistically significantly differed over time in terms of mathematics achievement. T-STEM charter schools showed a positive continuous increase over time, whereas non-T-STEM charter schools initially decreased in 2012 but then increased in 2013. When student demographics were taken into account, the results for T-STEM charter schools were not promising, but for two groups of students: Asian and Hispanic. For Asian and Hispanic students, T-STEM charter schools showed positive parabolic trajectory, which was not the case for non-T-STEM charter schools. T-STEM charter students started more disadvantaged as compared to their counterparts; however, it is encouraging that there were more positive results for Hispanic students who were also economically disadvantaged due to $96 \%$ of Hispanic students were economically disadvantaged. This finding reveals that T-STEM charter schools are successful with Hispanic and economically disadvantaged students with regard to mathematics achievement.

This study showed that STEM designation on charter schools was helpful for Hispanic, eco- nomically disadvantaged students. Students showed positive growth in mathematics, which is a very important finding, because the purpose of T-STEM academies was to improve academic achievement for all students where at least $50 \%$ has to be minority students (Young et al., 2011). Therefore, this study revealed that the funding and resources given to T-STEM academies was promising for underrepresented students.

\section{DISCUSSION}

In the literature, there were several studies about charter schools and their students' academic achievement. This study is the first to examine two variations of charter schools. Therefore, it maintains the importance of being the only study to examine two types of charter schools that one being STEM school. Charter schools were compared to traditional schools in several studies (see Barr et al., 2006; Gutierrez, 2012; Pardo, 2013; Rose 2013; Tuttle et al., 2010, 2013; Woodworth et al., 2008). In addition to that, previous studies focusing on comparing STEM schools to traditional public schools were conducted (see Bicer et al., 2015; Erdogan, 2014; Means et al., 2014; Öner, 2015; Öner \& Capraro, 2016; Philips, 2013; Wiswall et al., 2014; Young et al., 2011). However this study fills the gap in the literature in terms of investigating charter schools as they transform into a T-STEM academy.

In this study, results showed that T-STEM charter and non-TSTEM charter students' mathematics achievement longitudinally differed. The salient result of this study was the positive effect of STEM designation for Hispanic students. Previous studies' results showed that Hispanic students' mathematics achievement in STEM schools was higher than Hispanic students' scores in non-STEM schools in 
mathematics, reading, and science (Erdogan, 2014; Öner, 2015; Wiswall et al., 2014). In terms of questioning the effectiveness of STEM schools for Hispanic students, the results showed that STEM schools fulfill their promises for this specific group. The second important point of this finding was STEM schools' effectiveness for economically disadvantaged students because $96 \%$ of Hispanic students in this study were also economically disadvantaged; therefore, the results of this study lead researchers to look from another perspective that is related to T-STEM academies' goal, which is to improve students' mathematics achievement who are mostly minority and/or economically disadvantaged students. Other studies revealed that STEM schools were effective on economically disadvantaged students' mathematics achievement compared to non-STEM counterparts that includes all school types- charter, traditional so on- (Bicer et al., 2015; Erdogan, 2014) and this study showed similar results when T-STEM charter and non-TSTEM charters were compared.

From the implication point of view, this study does not specifically answer why most of $\mathrm{T}$ STEM academies were converted from charter schools, or why charter schools wanted to convert and apply for T-STEM designation; however, this study shed light on how T-STEM designation affected charter schools. It was shown that the T-STEM designation effect was positive for these schools over time in mathematics subject. The most important difference between T-STEM academies and charter schools were the STEM model in T-STEM academies (Öner \& Capraro, 2016). This model, TSTEM ADB, required integrated STEM teaching and learning. We did not intend to investigate specifically how successful the application of integrated STEM teaching and learning in TSTEM academies in this study; however, there was an obvious difference between two groups. Therefore, it would be fair to say that if the application of integrated STEM education is successful in these schools, then schools fulfill their promises and reach their goals.

As it was mentioned before a "well-structured STEM school culture" (Öner, in press) requires many components such as STEM curriculum and research-based instruction. These components are related to integrated STEM education. Integrated STEM education requires skills and knowledge on more than one STEM disciplines while one is an expert in one STEM discipline (Capraro, Capraro, \& Morgan, 2013). Integrated STEM education requires collaboration among teachers, administration, and stakeholders. STEM model in T-STEM schools demands for this type of collaboration. To determine deeply how successful integrated STEM education application in STEM schools, conducting qualitative studies in the future can be informative for researchers. This study helps us to understand that integrated STEM education is helpful to improve students' academic achievement when -if- integrated STEM education is applied, as it should be.

\section{Kaynakça}

Avery, S. (2010). T-STEM: Texas science, technology, engineering, and math. Retrieved from http://www.sedl.org/blueprint/files/avery blueprintforum stem_pres.pdf

Avery, S., Chambliss, D., Pruiett, R., \& Stotts, J. L. (2010). Texas science, technology, engineering, and mathematics academies design blueprint, rubric and glossary. Report of Texas High School Project T-STEM 
Initiative. Retrieved from http://www.edtx.org/uploads/general/pdf-downloads/misc$\underline{\text { PDFs/2011 TSTEM DesignBlueprint.pdf }}$

Barr, J. M., Sadovnik, A. R., \& Visconti, L. (2006). Charter schools and urban education improvement: A comparison of Newark's district and charter schools. The Urban Review, 38(4), 291-311.

Bicer, A., Navruz, B., Capraro, R. M., Capraro, M.M., Öner, A. T., \& Boedeker, P. (2015). STEM schools vs. non-STEM schools: Comparing students' mathematics growth rate on high-stakes test performance. International Journal of New Trends in Education and Their Implications, 6(1), 138-150.

Bryk, A. S. \& Raudenbush, S. W. (1988). Toward a more appropriate conceptualization of research on school effects: A three-level hierarchical linear model. American Journal of Education, 97(1), 65-108.

Capraro, R. M., Capraro, M. M., \& Morgan, J. (Eds.) (2013). STEM project-based learning: An integrated science, technology, engineering, and mathematics (STEM) approach (2nd ed.). Rotterdam, The Netherland: Sense.

Capraro, R. M., Capraro, M. M., Morgan, J., Scheurich, J., Jones, M., Huggins, K., ... \& Younes, R. (2015, In Press). The impact of sustained professional development in STEM in a diverse urban district. Journal of Educational Research.

Choi, S. (2012). A study on charter school effects on student achievement and on segregation in Florida public schools (Doctoral dissertation). Retrieved from ProQuest Dissertations and Theses database (UMI No. 3519299).

Educate Texas. (2013). T-STEM academy design blueprint. Retrieved from http://www.edtx.org/uploads/general/pdf-downloads/misc PDFs/EDTX TSTEM Academyblueprint.pdf

Erdogan, N. (2014). Modeling successful inclusive STEM high schools: An analysis of students' college entry indicators in Texas (Unpublished doctoral dissertation). Texas A\&M University, College Station, TX.

Erdogan, N. \& Stuessy, C. L. (2015). Modeling successful STEM high schools in the United States: An ecology framework. International Journal of Education in Mathematics, Science and Technology, 3(1), 77-92.

Gutierrez, M. H. (2012). Charter schools in greater Los Angeles: An evaluative comparison of charter schools visà-vis traditional public schools (Doctoral dissertation). Retrieved from ProQuest Dissertations and Theses database (UMI No. 3549282).

Hinojosa, M. (2009). A comparison of open enrollment charter schools and traditional public schools in a Texas region (Doctoral dissertation). Retrieved from ProQuest Dissertations and Theses database (UMI No. 3400333).

Hox, J. J. (2002). Multilevel analysis: Techniques and applications. Mahwah, NJ: Erlbaum.

Marshall, S. P. (2010). Re-imagining specialized STEM academies: Igniting and nurturing decidedly different minds, by design. Roeper Review, 32(1), 48-60. 
Means, B. Confrey, J., House, A., \& Bhanot, R. (2008). STEM high schools: Specialized science technology engineering and mathematics secondary schools in the U.S. (Bill and Melinda Gates Foundation Report). Retrieved from http://www.sri.com/work/projects

Means, B., House, A., Young, V., Wang, H., \& Lynch, S. (2013). Expanding access to STEM-focused education: What are the effects [White paper]? Washington, DC: SRI International.

Means, B., Wang, H., Young, V., House, A., \& Lynch, S. (2014, August). Effects of attending an inclusive STEM high school. Presentation for the DRK-12 PI meeting, Washington, DC.

Nathan, J. (1996). Charter schools: Creating hope and opportunity for American education. San Francisco, CA: Jossey Bass.

Öner, A. T. (2015). Longitudinal examination of Texas science, technology, engineering, and mathematics (STEM) academies (Unpublished doctoral dissertation). Texas A\&M University, College Station, TX.

Öner, A. T. (In press). STEM-FeTeMM okulları. In E. Çallı \& S. M. Çorlu (Eds.), STEM - fen, teknoloji, mühendislik, ve matematik eğitimi: Kuram ve uygulamaları (pp. xx-xx). İstanbul.

Öner, A. T., \& Capraro, R. M. (2016). Is STEM academy designation synonymous with higher student achievement? Education E Science, 41 (185), 1-17. Doi: 10.15390/EB.2016.3397

Osborne, J. W. (2000). Advantages of hierarchical linear modeling. Practical Assessment, Research, E Evaluation, 7(1). Retrieved from http://pareonline.net/getvn.asp?v=7\&n=1

Pardo, A. (2013). The relationship between student achievement and charter high schools in Washington, DC (Doctoral dissertation). Retrieved from ProQuest Dissertations and Theses database (UMI No. 3591495).

Peters-Burton, E. E., Lynch, S. J., Behrend, T. S., \& Means, B. B. (2014). Inclusive STEM high school design: 10 critical components. Theory Into Practice, 53(1), 64-71.

Philips, R. L. (2013). A comparison of college readiness among students enrolled in Texas science, technology, engineering, and mathematics academies and traditional comprehensive high schools (Doctoral dissertation). Retrieved from ProQuest Dissertations and Theses database (UMI No. 3567905).

President's Council of Advisors on Science and Technology. (2010). Prepare and inspire: K-12 education in science, technology, engineering, and math (STEM) for America's future. Washington, DC: Author.

Raudenbush, S. W., \& Bryk, A. S. (2002). Hierarchical linear models: Applications and data analysis methods (2nd ed.). Thousand Oaks, CA: Sage.

Rose, C. P. (2013). The academic impacts of attending a KIPP charter school in Arkansas (Doctoral dissertation). Retrieved from ProQuest Dissertations and Theses database (UMI No. 3589161).

Rosenbaum, P. R., \& Rubin, D. B. (1983). The central role of the propensity score in observational studies for causal effects. Biometrika, 70(1), 41-55.

Sahin, A., Willson, V. L., \& Capraro, R. M. (2013, April). Can Charter Schools Be Silver Bullets to the American Educational System? Paper presented at the annual meeting of American Educational Research Association. 
Scott, C. (2012). An investigation of science, technology, engineering and mathematics (STEM) focused high schools in the U.S. Journal of STEM Education, 13(5), 30-39.

Shadish, W. R., \& Steiner, P. M. (2010). A primer on propensity score analysis. Newborn and Infant Nursing Reviews, 10(1), 19-26.

Shrout, B. F. (2009). Comparative assessment of academic growth between retained freshmen at traditional Texas public schools and those at charter schools (Doctoral dissertation). Retrieved from ProQuest Dissertations and Theses database (UMI No. 3377853).

Snijders, T., \& Bosker, R. (1999). Multilevel analysis: An introduction to basic and advanced multilevel modeling. London: Sage.

Subotnik, R. F., Tai, H. R., Rickoff, R., \& Almarode, J. (2010). Specialized public high schools of science, mathematics, and technology and the STEM pipeline: What do we know now and what will we know in 5 years? Roeper Review, 32(1), 7-16.

Taylor, L. L., Alford, B. L., Rollikns, K. B., Brown, D. B., Stilisano, J. R., Waxman, H. C. (2011) Evaluation of Texas charter schools 2009-10. College Station, TX: Education Research Center at Texas A \& M University.

Texas Education Agency. (2014). Charter schools. Retrieved from: http://tea.texas.gov/Texas Schools/Charter Schools/

Texas Education Agency, \& Pearson. (2011). Technical digest for the academic year 2010-2011. Retrieved from http://tea.texas.gov

Texas Education Agency, \& Pearson. (2013). Technical digest for the academic year 2011-2012. Retrieved from http://tea.texas.gov

Texas Education Agency, \& Pearson. (2014). Technical digest for the academic year 2012-2013. Retrieved from http://tea.texas.gov

Thoemmes, F. J., \& Kim, E. S. (2011). A systematic review of propensity score methods in social sciences. Multivariate Behavioral Research, 46, 90-118.

Turner, J. E. (2013). Charter school education in Texas: Student achievement on the exit level assessment in math and science (Doctoral dissertation). Retrieved from ProQuest Dissertations and Theses database (UMI No. 3595362).

Tuttle, C. C., Gill, B., Gleason, P., Knechtel, V., Nichols-Barrer, I., \& Resch, A. (2013). KIPP middle schools: Impacts on achievement and other outcomes, final report. Washington, DC: Mathematica Policy Research.

Tuttle, C. C., Teh, B., Nichols-Barrer, I., Gill, B. P., \& Gleason, P. (June 2010). Student characteristics and achievement in 22 KIPP middle schools. Washington, DC: Mathematica Policy Research.

Tuttle, C. C., Teh, B., Nichols-Barrer, I., Gill, B. P., \& Gleason, P. (July 2010). Supplemental analytical sample equivalence tables for student characteristics and achievement in 22 KIPP middle schools: A report from the National Evaluation of KIPP Middle Schools. Washington, DC: Mathematica Policy Research. 
U.S. Department of Commerce Economics and Statistics Administration. (2011, July) STEM: Good jobs now and for the future (Issue Brief No. 03-11). Washington, DC: Langdon, McKittrick, Beede, Khan, \& Doms.

Wiswall, M., Stiefel, L., Schwartz, A. E., \& Boccardo, J. (2014). Does attending a STEM high school improve student performance? Evidence from New York City. Economics of Education Review, 40, 93105.

Woodworth, K. R., David, J. L., Guha, R., Wang, H., \& Lopez-Torkos, A. (2008). San Francisco Bay Area KIPP schools: A study of early implementation and achievement. Final report. Menlo Park, CA: SRI International.

Young, M. V., House, A., Wang, H., Singleton, C., \& Klopfenstein, K. (2011, May). Inclusive STEM schools: Early promise in Texas and unanswered questions. Paper prepared for the National Academies Board on Science Education and Board on Testing and Assessment for "Highly Successful STEM Schools or Programs for K-12 STEM Education: A Workshop", Washington, DC.

\section{Acknowledgements}

Authors would like to thank Aggie STEM Center and Texas Education Agency for providing data. 